\title{
Commentary Corticosteroids to prevent postextubation upper airway obstruction: the evidence mounts
}

\author{
Scott K Epstein
}

Tufts University School of Medicine, Pulmonary, Critical Care, and Sleep Medicine Division, Tufts-New England Medical Center, Harrison Avenue, Boston, Massachusetts 02111, USA

Corresponding author: Scott K Epstein, Scott.Epstein@tufts.edu

Published: 14 August 2007

This article is online at http://ccforum.com/content/11/4/156

(c) 2007 BioMed Central Ltd

See related research by Lee et al., http://ccforum.com/content/11/4/R72

\begin{abstract}
Intubation of the airway can lead to laryngotracheal injury, resulting in extubation failure from upper airway obstruction (UAO). A number of factors can help to identify patients who are at greatest risk for postextubation UAO. Three randomized controlled trials demonstrate that prophylactic corticosteroids decrease the risk for postextubation UAO and probably the need for re-intubation.
\end{abstract}

Extubation failure (the need for re-intubation) is associated with increased intensive care unit and hospital mortality, increased length of stay in the intensive care unit and hospital, greater need for tracheostomy and for long-term acute care, and increased costs. Underlying severity of illness, premorbid health status, and complications directly associated with re-intubation fail to explain the adverse outcomes seen with extubation failure. Clinical deterioration between the time of extubation and the re-establishment of ventilatory support may provide the best explanation. Therefore, preventing extubation failure has the potential to improve outcome.

The study reported by Lee and coworkers [1] is one of a series of recent investigations examining whether corticosteroids can prevent postextubation upper airway obstruction (UAO), which is a common cause of extubation failure. Intubation and the endotracheal tube (ETT) may cause laryngotracheal injury, resulting in inflammation, mucosal ulceration, edema, or granuloma formation. This can lead to glottic or subglottic narrowing, which manifests as stridor, respiratory distress, or respiratory failure after removal of the ETT. Factors associated with increased risk for postextubation UAO include female sex (probably resulting from small airway size), trauma patient, age above 80 years, excessively mobile or overly large ETT size, ratio of ETT size to laryngeal diameter above $45 \%$, ratio of patient height to
Critical Care 2007, 11:156 (doi:10.1186/cc5976)

tube diameter, duration of intubation, tracheal infection, absence of cough, absence of sedation, low Glasgow Coma Scale score, or excess cuff pressure [2-5].

Research into detection of UAO, with the ETT in place, has recently focused on using the quantitative cuff leak test [6]. During this maneuver the patient breathes on assist control ventilation, the endotracheal cuff is deflated, and the difference between inspired and expired tidal volume is compared. An obstructed upper airway results in similar inspiratory and expiratory volumes, whereas a patent airway results in a substantial difference as a large volume of gas escapes around the tube. This quantitative cuff leak can be reported as either a percentage of inspired tidal volume or as an absolute cuff leak volume (CLV). Previous investigators have found that the risk for postextubation stridor is increased when CLV is less than approximately $12 \%$ to $25 \%$ of inspired volume or an absolute value of less than 110 to $130 \mathrm{ml}$ [2,6-9].

Although previous studies conducted in pediatric patients found that corticosteroids reduce the prevalence of postextubation UAO by nearly $40 \%$ and may reduce the need for re-intubation [10], earlier controlled trials in mechanically ventilated adults did not corroborate those findings [11]. Francois and colleagues [12] recently compared $20 \mathrm{mg}$ methylprednisolone (given every 4 hours for 12 hours before extubation) with placebo in nearly 700 adults patients who had been intubated for at least 36 hours. Corticosteroid pretreatment was associated with decreased risk for postextubation UAO (3\% versus $22 \%$ ), need for re-intubation ( $4 \%$ versus $8 \%$ ), and need for re-intubation secondary to UAO (0.3\% versus $4 \%)$. The number needed to treat (NNT) was eight to prevent one case of stridor and 26 to prevent one case of re-intubation. Cheng and colleagues [2] used a

$\mathrm{CLV}=$ cuff leak volume; ETT $=$ endotracheal tube; NNT = number needed to treat; $\mathrm{UAO}=$ upper airway obstruction. 
reduced CLV ( $\leq 24 \%$ of inspired tidal volume) to define and study patients at high risk for postextubation UAO. Patients randomly assigned to methylprednisolone $(40 \mathrm{mg}$ every 6 hours for four doses) were less likely either to experience stridor $(7 \%$ versus $30 \%)$ or to require re-intubation $(7 \%$ versus $19 \%$ ) than were those receiving placebo.

The study reported in this issue of Critical Care [1] also targeted high-risk patients by examining those ventilated for at least 48 hours and with a CLV below $110 \mathrm{ml}$. Patients were randomly assigned to receive placebo or dexamethasone $5 \mathrm{mg}$ every 6 hours for 24 hours, and were then extubated 24 hours later. The dexamethasone group was less likely to develop postextubation stridor (10\% versus $27.5 \%$; NNT $=5.7$ ) without a difference in need for re-intubation $(2.5 \%$ versus $5 \%$; NNT $=40)$. An important observation is that dexamethasone led to a significant increase in CLV that persisted for 24 hours after the last dose (for example, at the time of extubation). Given that no further improvement in CLV occurred after the last dose of dexamethasone, one could argue for immediate extubation at that time rather than waiting an additional 24 hours.

The study by Lee and coworkers [1] also revealed that 14 out of 285 in the non-randomized cohort (4.9\%), who had a CLV above $110 \mathrm{ml}$, developed stridor. Examining these patients and those randomly assigned to placebo, only $20 \%$ with postextubation UAO required re-intubation, possibly a result of the effective use of inhaled racemic adrenaline (epinephrine) and noninvasive ventilation. Among placebo patients, 73\% did not develop postextubation UAO, despite a CLV below $110 \mathrm{ml}$; similar findings have been noted by other investigators. A falsely low CLV may result from secretions adherent to or pooled around the ETT. Alternatively, with the cuff deflated, the patient may breathe additional tidal volume around the tube (in addition to machine delivered volume), leading to a falsely low measurement of inspired tidal volume. The resulting difference between inspired and expired tidal volume will then be falsely low. This phenomenon can be overcome by delivering the machine breath with the cuff inflated and then deflating the cuff just before expiration [13].

The evidence is now mounting that corticosteroids can prevent postextubation UAO, and possibly the need for reintubation, but should all patients be intubated for longer than 36 to 48 hours receive such therapy? Although a short course of corticosteroids may be relatively safe, further study is warranted. This author believes the focus should continue to be on targeting patients at greatest risk. Although the study by Francois and coworkers [12] examined an 'unselected' cohort, the $22 \%$ incidence of postextubation UAO suggests a high risk group. Using the CLV can help to identify a cohort at greater risk, but the sensitivity and specificity of the test is suboptimal. Using this test alone to determine need for prophylactic corticosteroids will result in an unnecessary 12 to 24 hour prolongation of intubation for three out of every four such patients. Another approach is to identify first a high-risk cohort based on clinical factors (for instance, age, sex, tube size, and so on) and then to apply CLV to determine which patients should receive corticosteroids before extubation.

\section{Competing interests}

The author declares that they have no competing interests.

\section{References}

1. Lee C-H, Peng M-J, Wu C-L: Dexamethasone to prevent postextubation airway obstruction in adults: a prospective, randomized, double-blind controlled study. Crit Care 2007, 11: R72.

2. Cheng $\mathrm{KC}$, Hou $\mathrm{CC}$, Huang $\mathrm{HC}$, Lin SC, Zhang $\mathrm{H}$ : Intravenous injection of methylprednisolone reduces the incidence of postextubation stridor in intensive care unit patients. Crit Care Med 2006, 34:1345-1350.

3. Epstein SK: Decision to extubate. Intensive Care Med 2002, 28: 535-546.

4. Kriner EJ, Shafazand S, Colice GL: The endotracheal tube cuffleak test as a predictor for postextubation stridor. Respir Care 2005, 50:1632-1638.

5. Maury E, Guglielminotti J, Alzieu M, Qureshi T, Guidet B, Offenstadt G: How to identify patients with no risk for postextubation stridor? J Crit Care 2004, 19:23-28.

6. Miller RL, Cole RP: Association between reduced cuff leak volume and postextubation stridor. Chest 1996, 110:10351040.

7. De Bast Y, De Backer D, Moraine JJ, Lemaire M, Vandenborght C, Vincent JL: The cuff leak test to predict failure of tracheal extubation for laryngeal edema. Intensive Care Med 2002, 28: 1267-1272.

8. Jaber $S$, Chanques $G$, Matecki S, Ramonatxo M, Vergne $C$ Souche B, Perrigault PF, Eledjam JJ: Post-extubation stridor in intensive care unit patients. Risk factors evaluation and importance of the cuff-leak test. Intensive Care Med 2003, 29: 69-74.

9. Sandhu RS, Pasquale MD, Miller K, Wasser TE: Measurement of endotracheal tube cuff leak to predict postextubation stridor and need for reintubation. J Am Coll Surg 2000, 190:682-687.

10. Markovitz BP, Randolph AG: Corticosteroids for the prevention of reintubation and postextubation stridor in pediatric patients: a meta-analysis. Pediatr Crit Care Med 2002, 3:223226.

11. Meade MO, Guyatt GH, Cook DJ, Sinuff T, Butler R: Trials of corticosteroids to prevent postextubation airway complications. Chest 2001, 120:464S-468S.

12. Francois B, Bellissant E, Gissot V, Desachy A, Normand S, Boulain T, Brenet O, Preux PM, Vignon P: 12-h pretreatment with methylprednisolone versus placebo for prevention of postextubation laryngeal oedema: a randomised double-blind trial. Lancet 2007, 369:1083-1089.

13. Prinianakis G, Alexopoulou C, Mamidakis E, Kondili E, Georgopoulos D: Determinants of the cuff-leak test: a physiological study. Crit Care 2005, 9:R24-R31. 